the artery sutured laterally with fine sillk sutures. A graft taken from the (Fig. 3) internal saphenous vein was sutured to the opposite side of the sutured artery (Fig. 4). The operation lasted two hours. On removing the clamps the circulation was perfect, and there was no haemorrhage from the line of suture. The wound was closed without drainage and the stitches were removed on the tenth day.

The patient made an uninterrupted recovery. I examined him fire months after the operation; he was then doing light duty, and the circulation in the limb was normal.

\section{THE CHARACTER AND TREATMENT OF FROST-BITE.}

By H. E. MUNROE, M.D., C.M.McGiLL, L.R.C.P. AND S.EDIN.,

Major C.A.M.C., Surgeon to Saskatoon City Hospital, Canada, AND CANADIAN STATIONARY HOSPITAL.

WHILE reading with interest The Memorandum on the Treatment of Injuries in War, issued under the authority of the War Office, it occurred to me that, in view of the possibility of another winter campaign and the importance of adopting the proper treatment in "frost-bite," a few remarks on this subject might be of interest to those who, owing to climatic conditions, may not have had an opportunity of treating this injury.

The prophylactic measures, so far as protection of the feet is concerned, may be summed up in three phrases: (1) Loose, water-tight boots should bo worn; (2) dry woollen socks changed daily; (3) maintenance of the circulation of the feet by moving them freely.

The toes and heel are the parts most liable to be attacked, and, unless the circulation is re-established by friction or heat, the condition will spread until the whole foot is involved. This extension is painless. Pain is experienced before the part becomes frozen. A few sharp stings following a period of pain is the usual experience. These stings, followed suddenly by cessation of pain, is a sure indication that the limb is being frozen.

I had an opportunity of observing a few cases among the soldiers from Flanders during the winter of 1914-15. They could not be regarded as true "frost-bite," but rather erythema pernio, as the borders of the feet and not the toes were the parts involved.

Three degrees of frost bite were generally recognized: (1) Erythematous, (2) bullous, (3) gangrenous.

1. In the first degree the skin only is affected. The anaemic appearance rapidly disappears with friction or exposure to the higher temperature. The localized anaemia is followed by erythema and occasionally slight oedema, which disappears in a few days.

2 . 'The second degree is characterized by the formation of blebs filled with serum. These blebs, as a rule, appear within eighteen hours of exposure of the part to a higher temperature. The skin is a bluish colour, more oedema is present than in frost-bites of the first degree, which indicates the involvement of the superficial tissues in addition to the skin.

3. The third degree follows the exposure of the part to prolonged intense cold, and involves the skin and superficial and deep tissues. If the part is seen when in a frozen condition it is white, cold, and sensation is absent; on exposure to a higher temperature it assumes a swollen and congested appearance. Within eighteen hours the proximal area of the limb involved assumes the characteristic erythema of the first degree, while lower down the limb we have an area of blebs indicating the second degree of frost-bite. The distal portion of the limb-namely, the heel oi toes-becomes cyanotic and later shrunken, and may become definitely gangrenous within forty-eight hours.

The treatment consists in using every available means to prevent an excessive reaction. Left to nature tho partially devitalized cells become destroyed by the sudden engorgement of the part. The more severe the frost-bite the more oedema is present and the more pain is complained of. If the patient is secn while the part is still frozen, the circulation should be gradually restored by placing the limb in ice-cold water, or by using gentle friction, with snow when available. The part may be corered with gauze or absorbent cotton, which should be trequently saturated with an eraporating lotion. I use a lotion composed of liq. plumbi subacet. $3 j$, spt. rectif. $z$ iij, aquam ad $\xi j$. When blebs form, they should be punctured. The application of the evaporating lotion is continued for the first twenty four to thirty-six hours, until the swelling begins to subside or there is an indication of a cyanotic or shrunken appearance in the toes, or fingers if the hand is involved. Hot boracic fomentations should now be $\mathrm{cm}$. ployed in order to overcome the reactive vasomotor con. striction and consequent anaemia of the parts. This treatment is liept up for twenty-four lours, or until tho cyanotic and shrunken appearance disappears or gangrene has definitely formed.

Amputation of a gangrenous area should not be under. taken until the line of demarcation between the dead and healthy tissues is well formed, which indicates the line of operation. While waiting until amputation should be performed, a powder of boracic acid and charcoal may be employed if any moisture or perceptible odour is present.

\section{ftemtaranda:}

\section{MEDICAL, SURGICAL, OBSTETRICAL}

APPENDICITIS AND MEDICAI, TREATMENT.

I HAVE full notes of 9 typical cases of appendicitis which occurred among the average daily population of 3,000 Indian labourers, consisting chiefly of Tamils and Telugas during a space of eight years. These cases were of all grades of severity, and in at least five of them inmediate surgical operation was deemed advisable. But as is well known, the illiterate coolie classes always dread the knife, and owing to the strong opposition raised in every one of these individual cases, the idea of operation had to be abandoned. Blood examination revealed leucocytosis, and there were other unmistakable symptoms of the malady, subjective and objective, present as well. In the last two cases of the series, one a male and the other a female, the life of each was considered to be in imminent danger, as it was thought that infection of the general peritoneum through perforation of the appendix, could occur at any hour. Of these 9 cases, 8 recovered fully under conservative treatment; the one death was in an infant 15 months old. Post-mortem examination showed that the appendix was gangrenous and that there was generalized peritonitis; the causative organism of the infection was the pneumo. coccus; the appendix was widely ruptured, and an orange pip was found adlierent to its interior. The adhesions round the affected cul-de-sac were poorly formed and were therefore unable to protect the general peritoneum.

The recovery in the last two cases was really most instructive. A careful consideration of the facts of these cases fully justifies the opinion that even seemingly hopeless cases might at times do well under proper medical care and treatment.

$$
\text { T. A. R. Aiyar, L.R.C.P. and S.Edin., }
$$

Sitiawan, Lower Perak, F.M.S.

$$
\text { L.F.P. and S.Glasg. }
$$

\section{PNEUMOTHORAX FOLLOWING PNEUMONIA.}

A BRICKLAYER, aged 40, of healthy appearance, had had a cold for a few days before he sought adrice but had been able to continue at work. I saw him about midday on October 6th, diagnosed pneumonia, and ordered tho routine treatment.

At 10 p.m. of the same day I was hastily summoned as he was feeling very ill. He had great dyspnoea and marked cyanosis, and pain over the right hypochondriac region, and evidently was suffering from a good deal of shock judging by his small and rapid pulse. Percussion over the right lung and liver areas was markedly tym. panitic, and with the bruit d'airain and a very soft amphoric breatling over the right posterior base gave all the signs of pneumothorax.

The liver on deep pressure could be felt extending to four fingerbreadths below the costal margin, the heart appeared to be little displaced, no fluid could at any time be made out. A few days later the sputum was examined by the borough bacteriologist, and found to contain numerous pneumocooci, a fairly plentiful number. of staphylococci, but no tubercle bacilli.

The patient improved rapidly, but the air was slowly 